\title{
The Effect of American Translated Brand Name Cue on Brand Association in Korean Market
}

\author{
Mahmood A. Awan and Ho Han Chiang
}

\begin{abstract}
The objective of this research is to explore consumer attitudes in South Korea towards local and American imported brand (AIB) products. This is done against a background of increasing prevalence of American brand names and stereotypes of Country-of-Origin effect. A further objective is to study the differences if any, in the consumer purchase decisions of AIB and American translated brands (ATB) among Koreans and expatriates. A structured questionnaire administered face-to-face and online to $\mathbf{4 1 2}$ consumers of city of Daejeon, S. Korea was used. Attitudes of two (2) brands categorized as "American" in English and also translated in Korean were measured using a seven-point Likert scale. The results of the study suggest that products with American brand labels evoke consumers' high attention and enhances consumers' positive evaluation. This study adds to the body of knowledge on consumer behavior about country-of-origin effect and cultural differences in perception towards American brands. Products with American brand labels (not translated) can be a tool to attract consumers' attention. Thus one recommended strategy based on the current study for American brands marketers to Korea is to position the products on attributes of technology and quality, rather than economy and value for money.
\end{abstract}

Index Terms - South Korea, country of origin (COO) effect, American brands, brands, consumers, ethnocentrism.

\section{INTRODUCTION}

A free trade agreement was signed in 2010 between USA and South Korea to increase opportunities for U.S. businesses, farmers and workers through improved access for their products and doubling the U.S. exports in five years [1]. It is expected that the agreement will promote the further integration of the U. S. and Korean economies and enhance the competitiveness of U.S. business in the words 12th largest economy. The agreement would eliminate tariffs in over $95 \%$ of industrial and consumer goods made in five years [2].

South Korea taste for western customer goods has made the country a key Asian market for companies in this industry from North America and Western Europe. Thus the U.S. organizations are offering products in the south Korean market that are similar in style and quality to what customer can find in the organizations home market in the U.S. [3]. According to [4] traditionally, South Korean consumers were homogeneous in nature, however they now appear to be rapidly embracing international influences, particularly with the respect to food. Higher levels of education, and travel abroad, international tourists, and technology, have all helped to broaden horizons and open the door to new and innovative

Manuscript received March 10, 2014; revised June 9, 2014.

The authors are with Sol Bridge International School of Business, Daejeon, South Korea (e-mail: mawan@solbridge.ac.kr). products.

South Korea's population is aging rapidly. Coupled with the increase in the life expectancies, seniors are expected to account for over $20 \%$ off the population by 2026 . These factors could lead to increased demand for Food Products in smaller, convenient package sizes. South Korea imports $60-70 \%$ of its food requirement and runs a significant food trade deficit. This creates opportunities for American branded food items in the Korean market.

South Korea is one of the largest retail markets in Asia and consumer goods companies in the country reported a total of $\$ 221$ billion in retail sales in 2010. This made it the fifth largest country for retail sales in the region, behind China, Japan, India, and Indonesia. Also it is expected that Asia's retail market will grow from $\$ 248$ billion to $\$ 319$ billion between 2011 and 2015, and sales in the consumer goods sector could expand by $2.3 \%$ a year or the same period. With $70 \%$ off the South Korea population classified by Price water Cooper as being part of the main retail target age of 15 to 64 years old, the outlook for its consumer goods products in industry seems positive.

The present research attempts to obtain a better understanding of attitudes and preferences of Korean consumers with regards to American vs local brands, and to evaluate their relative strengths in terms of differentiating features. In addition, the extent to which consumer ethnocentrism accounts for a positive bias towards local domestic brands and a negative bias against products originating from USA, is examined, to identify if there was any strong domestic country bias in the choice of brands.

The finding could be of interest to US companies in their formulation of foreign marketing strategies by offering a better understanding of how the foreign brands are likely to be perceived in relation to domestic products and those originating from other competing countries in to Korea. The remainder of this paper is organized as follows. Following the introduction, the second section provides a relative literature review. The third section presents the research methods use, and analyses. The fourth section discusses the results and the findings of this study. Finally, the study concludes with a discussion of the limitation of the study, and the future research in this field is presented as well.

\section{LITERATURE REVIEW}

For organizations marketing their products and services overseas. A critical decision which they must make is, whether to standardize or customize the various elements of their brand. Within the branding elements, product name is perceived to be the most important explicit peripheral cue that captures the immediate attention of customers, its 
influences, consumer perception and evaluation of the product. The consumer uses brand name frequently which represents a composite of information about the product's attributes. Perception of quality of the product is an important element relating to the brand use. If all brands in a category are seen as sharing a similar quality, then the particular brand image plays a role in purchase process.

A brand name not only conveys a specific set of attributes and benefits to buyers but also expresses the values of the producer and the positioning of the product in the market. Brand equity is the marketing and financial value associated with the brand's strength in a market [5]. "Brands have never been more important than they are today. The accelerating rate of turbulent change, the volatility of economics and markets, the relentless progress of technology and innovation, and increasing market fragmentation have caused the destruction of many companies and products they have failed to develop the lifeline of a strong brand." ([6], p xiii). A host of foreign branded goods are now freely used as well as easily available. A related trend contributing to these shifts has been the reduction in trade barriers due to trade agreements, and the globalization influence of associations such as WTO. This also provides opportunities for American Food brands to freely market in South Korea.

\section{A. Impact of the English Labels on Product Evaluation}

In Asia, there is a long-standing assumption that English capability is a prerequisite for entry to the global economy. Some Asian government policies indicate the success of English and the role of so-called international language. Simultaneously, the success of market economies has made the marketing message itself an international language of sorts. Consumers encounter product information daily from numerous sources. One central channel in this marketing communication is language in packaging, advertising, and product information. Chen, Warden, and Chang [7] have studied the effect, called language of origin (LOO). Similarly, [8] have studied the effect of bilingual (Chinese and English) vs Chinese only store signs to see if it impacts foreign brand evaluation and purchase intentions. However, no such study was found for the Korean consumers for consumer goods.

TABLE I: MEAN VALUES AND STANDARD DEVIATIONS OF ITEMS

\begin{tabular}{|c|c|c|c|c|c|c|}
\hline \multirow{2}{*}{ Items } & & \multicolumn{2}{|c|}{ Hi-English Ability } & & \multicolumn{2}{|c|}{ Low-English Ability } \\
\hline & & High & Low & & High & Low \\
\hline $\begin{array}{l}\text { ConAtt } \\
(2 \text { items) }\end{array}$ & $(H i g h:>8)$ & $\begin{array}{l}11.18 \\
-1.72\end{array}$ & $\begin{array}{r}6.31 \\
-1.55\end{array}$ & $($ High: $>7)$ & $\begin{array}{r}9.26 \\
-1.29\end{array}$ & $\begin{array}{r}6.07 \\
-0.92\end{array}$ \\
\hline $\begin{array}{l}\text { ProdEng } \\
(5 \text { items })\end{array}$ & (High:>18) & $\begin{array}{l}17.38 \\
-2.67\end{array}$ & $\begin{array}{l}8.63 \\
-2.98\end{array}$ & $($ High:>10) & $\begin{array}{l}14.17 \\
-2.82\end{array}$ & $\begin{array}{c}7.17 \\
-2.06\end{array}$ \\
\hline $\begin{array}{l}\text { Amebra } \\
\text { (5 items) }\end{array}$ & $($ High:>12) & $\begin{array}{l}16.24 \\
-2.72\end{array}$ & $\begin{array}{r}8.08 \\
-2.49\end{array}$ & $($ High: $>10)$ & $\begin{array}{l}14.22 \\
-2.12\end{array}$ & $\begin{array}{c}7.33 \\
-2.12\end{array}$ \\
\hline $\begin{array}{l}\text { CultuId } \\
\text { (5 items) }\end{array}$ & $(H i g h:>17)$ & $\begin{array}{l}20.44 \\
-2.03\end{array}$ & $\begin{array}{l}13.89 \\
-2.98\end{array}$ & (High: $>18)$ & $\begin{array}{l}17.48 \\
-2.34\end{array}$ & $\begin{array}{l}11.05 \\
-2.68\end{array}$ \\
\hline
\end{tabular}

Note: (1) Standard deviations reported in parentheses.

(2) Each survey item is 5-point Likert scale

TABLE II: ANOVA RESULTS OF INDEPENDENT VARIABLE AS FACTORS ENGLISH ABILITY

\begin{tabular}{cccccccc}
\hline \hline Source & & \multicolumn{2}{c}{ [1] Products Attention } & \multicolumn{2}{c}{ [2] Products Evaluation } & \multicolumn{2}{c}{ [3] A-Brand Pro Eva } \\
\hline & df & $F$ & $p$-value & $F$ & $p$-value & F & -value \\
\hline Eng $(E)$ & 1 & 40.15 & $0.00^{*}$ & 50.77 & $0.00 *$ & & \\
Error & 409 & & & & & & \\
$* p<0.05$ & & & & & &
\end{tabular}

TABLE III: ANOVA RESULTS OF INDEPENDENT VARIABLE AS FACTORS CULTURAL IDENTITY

\begin{tabular}{|c|c|c|c|c|c|c|c|}
\hline \multirow[t]{2}{*}{ Souree } & \multirow[b]{2}{*}{ df } & \multicolumn{2}{|c|}{ (1)Products Attention } & \multicolumn{2}{|c|}{ (2)Products Evaluation } & \multicolumn{2}{|c|}{ (3)A-Brand Pro Eva } \\
\hline & & $F$ & p-value & $F$ & p-value & $F$ & $p$-value \\
\hline Cultural Id (CID) & 1 & 82.89 & $0.00^{*}$ & 48.14 & $0.00 *$ & 74.86 & $0.00^{*}$ \\
\hline Eng $(E)$ & 1 & 76.47 & $0.00^{*}$ & 28.44 & $0.00 *$ & 15.30 & $0.00 *$ \\
\hline$C I D \times E$ & 1 & 3.19 & 0.07 & 0.02 & 0.88 & 2.32 & 0.13 \\
\hline Error & 407 & & & & & & \\
\hline
\end{tabular}

\section{B. Country all of Origin (COO)}

An important consideration for the methodology consumers utilize for purchase decisions has been also referred to as the "Country of Origin" (COO) effect. This individual bias based on perceptions and attitudes has a significant impact on how consumers make their purchasing decisions. Although $\mathrm{COO}$ image measurements in Asian 
country markets have been attempted [9], there is a lack of concrete information on consumer attitudes, preferences and marketplace behavior with regards to foreign brand names in these markets.

Rosenbloom, Haefner, \& Lee [10] have studied the Chinese consumer decision making in relation to ten global brands. It was shown that global brand familiarity was a predictor for seven brands. Similarly, familiarity and trust increased the likelihood of purchase intention. Deli-Grey, Haefner, and Rosenbloom [11] also showed that brand liking is the strongest overall predictor of global brand purchase intent. Similar results were shown from respondents of Hungary and Bulgaria [12]. No such study on COO was found by the authors for South Korean consumers.

\section{Consumer Ethnocentrism (CE)}

Ethnocentrism is defined as "the local tendency of perception to view their own group as the center of the universe, to interpret other social units from the perspective of their own group, and to reject persons who are culturally dissimilar while blindingly accepting those what are culturally like themselves[13]. They also developed the CETSCALE to measure consumer ethnocentrism. Consumer ethnocentrism has been more recently been termed "domestic country bias" by [14)].

According to Kaynak and Kara [15], the level of CE varies across individuals, cultures, and countries and it can influence attitudes and intentions towards buying foreign goods. Singh et al.,[16] have shown that CE could exist online as well where it relates to consumer reactions to global and local appeals. The impact of CE may depend on the foreign product brand's country of origin, as shown by Balabanis and Diamantopoulos. No study of CE exists in literature for South Korean consumers.

\section{Hypotheses of the Study}

Based on the above literature review current study attempts to bridge the gaps using the following hypotheses:

H1: Comparing to products without English label, consumers pay more attention to products with English label

H2: Comparing to products without English label, consumers have positive evaluation toward products with English label.

H3: Consumers' attention to products with English label is affected by their English ability and American cultural identity simultaneously.

H4: Consumers' positive evaluation of products with English label is affected by their English ability and American cultural identity simultaneously.

H5: Compared to Korean brand products, consumer have a positive evaluation of American brand products.

H6: Consumers' positive evaluation of American brand products is affected by their English ability and American cultural identity simultaneously.

This study will help bridge the gap in three ways. Firstly it tests three brand naming approaches on labels all consumer goods in respect of using international brand name. The three approaches are using original name, translating name in Korean, and using both English and Korean name. Secondly it examines their relationship of consumer ethnocentrism with the Korean consumer attitude towards these approaches.
Finally the study investigates how country of origin COO moderates and their relationship between $\mathrm{CE}$ and Korean consumers' attitude towards these approaches.

\section{RESEARCH METHODS AND ANALYSES}

\section{A. Products}

In the survey, we analyzed consumers' preferences toward products with English labels and American brand products. We selected demonstrated products which already exist in the Korea marketplace. They are "Del Monte Juice" and "Florida's Natural Juice". We chose juices as our demonstrated products as they are one of the common daily products among consumers, representing an appropriate examples for our study. Moreover, consumers could evaluate these products easier than other daily products.

\section{B. Respondents}

This study explores the influences of products with English labels and American brand products on consumer behavior toward the possession of daily products. All respondents were Korean undergraduate students from one major university in Korea. Respondents were classified into high/low English ability to fill in designed questionnaire expressing their opinions about this topic.

University students, instead of random respondents, were used to increase the homogeneity of the sample and to minimize the random error caused by selecting the general public [17]. In general, students with higher educational level will usually have better knowledge and ability to judge and analyze events. Therefore undergraduate students are suitable for this survey.

Original responses were 523. After excluding invalid answers, we were left with $412(78 \%) .43$ percent of the total sample was male $\left(\mathrm{n}_{\text {Male }}=177\right)$ and 57 percent of the total sample was female $\left(\mathrm{n}_{\text {Female }}=235\right)$.

\section{Data Collection and Sample Characteristics}

Participants completed the on-line or off-line survey. When completing the survey, the product information sheet consisting of picture of the product - was available for the respondents (See Fig. 1).

All measures (See Fig. 1) employed in the surveys were 5-point Likert scale, ranging from 1 (strongly disagree) to 5 (strongly agree). We translated our questionnaires into Korean using a back-translation to assure comparability and equivalence in the meaning of questionnaires [18], [19]. We adopted these items from previous studies.

To measure consumers' attention toward products (reliability coefficient - Cronbach alpha, $\alpha=0.82$ ), we used the items from Speed and Thompson (2000). To measure consumers' evaluation on products, preference on American brand name or Korean brand name $(\alpha=0.85, \alpha=0.92, \alpha=$ 0.91 ), we used the items by [20].

To measure cultural identity ( $\alpha=0.85$ ), we followed the scale developed by [21]. Our Cronbach's alphas for all the scales were above 0.6. This is considered an acceptable Cronbach's alpha cutoff according to [22].

In this study, we adopt ANOVA (analyses of variance) to consumers' responses. We classified respondents into 
high/low English ability, which affected consumers' preferences toward products with English labels and American brand products.
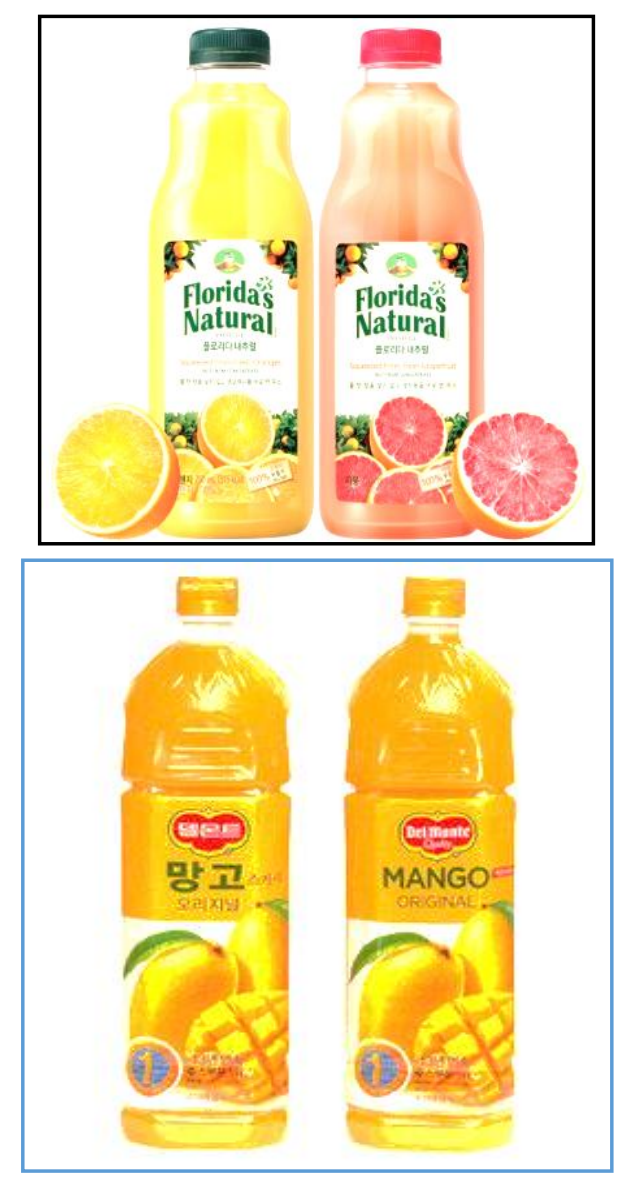

Fig. 1. Two brands used in English and Korean.

We performed five 2 (English ability: high, low) $\times 2$ (factors: high, low) ANOVA tests in order to obtain results that can give more detailed and interesting results than just one-way ANOVA. We sorted the four factors into high and low, with respect to the median of the sum of the items. Then, we also used one-way ANOVA to test for the interaction effects of each component specified in our hypotheses.

Table I shows the mean and standard deviations (SD) of each scale. The mean of consumers' attention on products(ConAtt) in Hi-English Ability is 8. This means that in the group of Hi-English Ability if one respondent's sum of the items of consumers' attention on products is larger than 8 , then this respondent's attitude toward consumers' attention on products is highconsumers' attention on products. In Table I, the variable Products with English label is ProdEng, American Brand Products is Amebra and Cultural identity is CultuId.

\section{RESUlt ANALYSIS}

English is the one of the most important language around the world. Especially in Asia, people generally are proud of themselves if they could speak English well or have good English ability. Through the empirical tests of the study, we try to explore the purchasing preferences of all potential consumers, whose English ability is high or low, to see whether there are any differences when these two types of consumers face products with English labels and American brand products. The results provide useful information for marketer when making marketing decisions

In Table II, consumers' English ability affects their attention to products with English label $(F(1,409)=40.15$, $\left.p<0.05 ; \operatorname{Mean}_{\mathrm{HE}}=5.77>\operatorname{Mean}_{\mathrm{LE}}=4.43\right)$. H1 is supported and consumers with high English ability pay more attention than consumers' with low English ability to products with English label. Table 1 shows that consumers' English ability affects their positive evaluation of products with English label $\left(F(1,409)=50.77, p<0.05 ; \mathrm{M}_{\mathrm{HE}}=13.79>\mathrm{M}_{\mathrm{LE}}=10.48\right)$. Thus $\mathrm{H} 2$ is supported and consumers with high English ability have stronger positive evaluation of products with English label than that of consumers with low English ability.

Table 3 below describes the relationships among American cultural identity, English ability, Products attention, Products Evaluation and evaluation of American brand products. The results show that the interaction effect is insignificant overall. Thus, H3 $(F(1,407)=3.19, p=0.07)$, H4 $(F(1,407)=0.02, p=0.88)$ are not supported. However, both American cultural identity and English ability significantly affect Products Attention $(F(1,407)=82.89$, $p<0.05, \mathrm{M}_{\mathrm{HAA}}=5.85>\mathrm{M}_{\mathrm{LAA}}=4.19 ; F(1,407)=76.47$, $\left.p<0.05, \mathrm{M}_{\mathrm{HEA}}=5.45>\mathrm{M}_{\mathrm{LEA}}=4.58\right)$, and Products Evaluation $\left(F(1,407)=48.14, p<0.05, \mathrm{M}_{\mathrm{HAE}}=13.66>\mathrm{M}_{\mathrm{LAE}}\right.$ $=10.47 ; F(1,407)=28.44, p<0.05, \mathrm{M}_{\mathrm{HEE}}=13.29>\mathrm{M}_{\mathrm{LEE}}=$ 10.84). From the results of mean comparison, high American cultural identity and high English ability have higher impacts than lower counterparts on two dependent variables. Appendix 1 shows the interaction effect of American cultural identity and English ability.

\section{Discussion AND Future RESEARCH RECOMMENDATIONS}

This study explores when consumers face products with English labels and American brand products, whether they have higher attention and positive evaluation on these products. In addition, introducing consumers' high/low American cultural identity into the empirical tests, this study further extends the extent to check any differences between consumers' attention and evaluation on these products.

Comparing to products with Korean labels, products with English labels evoke consumers' higher attention and enhances consumers' positive evaluation. The possible reason maybe because English creates different and novel feelings to consumers causing their attention to check the products on the shelf. Products with English labels not only can be a tool to attract consumers' attention, but also add consumers' positive evaluation on these products.

The degree of American cultural identity affects consumers' attention and positive evaluation on products as well. When consumers are high American cultural identity, they are easy to be attracted by products with English labels and American brand products. The possible reason comes from that consumers with high American cultural identity usually are familiar with American culture or have good English ability; these factors let these consumers be attracted by English with products labels or American brand products easily. In addition, consumers with high degree of American cultural identity, their positive evaluation on products with 
English labels are higher than products with Korean labels. Relatively this positive evaluation is lower while consumers are low American cultural identity. Probably consumers with high American cultural identity have more positive attitude toward American culture and this attitude indirectly reflects their evaluation on products with English labels and American brand products.

\section{A. Implications}

It can be concluded from the study that when comparing to products with Korean labels, products with English labels and American brand products could attract more consumers' attention and cause consumers' positive evaluation on products. Furthermore, consumers with low American cultural identity are also possibly attracted by products with English labels and American brand products. For managers of the American consumer brands, the implications are clear. USA companies which would like to sell products in Korea may use English labels or use the original English labels on their products. They do not need to change the label language into Korean.

\section{B. Limitations}

At least four issues limit the findings of the current research. Firstly, the results are based on a small population of city of Dejon in South Korea, thus it may not be generalized for the country. Secondly, for this study only one category of consumer products with specific American brands, was used. Thirdly, there could be other variables like lifestyle or political views, could influence the consumer ethnocentrism and purchase intentions towards certain international brands. Finally, the competitor Korean brands image was not studied which could have a direct effect on the consumer decision making towards these American brands.

Thus, further studies can look for other variables such as cultural sensitivity and global openness which may influence the Korean consumers' evaluation of different foreign brand-naming strategies.

\section{REFERENCES}

[1] Y. Park, "The impact of the US-Korea free trade agreement on both economies," International Journal of Korean Studies, vol. 17, no. 1, pp 95-107, 2013.

[2] FTIS (nod). The US-South Korea Free Trade Agreement. [Online]. Available:

http://www.sice.oas.org/TPD/USA_KOR/Negotiations/Overview_De c10.pdf

[3] B. Njau. (2013). Western influence drives South Korean consumer goods industry. [Online]. Available: http://www.fdiintelligence.com/Special-Reports/Western-influence-dr ives-South-Korean-consumer-goods-industry?ct=true

[4] The South Korean Consumer Behavior, Attitudes and Perceptions toward Food Products. [Online]. Available: http://www.ats-sea.agr.gc.ca/asi/5799-eng.htm

[5] Y. Fan, "The national image of global brands," Journal of brand Management, vol. 9, no. 3, pp. 180-193, 2002.

[6] P. Temporal, Advanced Brand Management: Managing Brands in a Changing World, $2^{\text {nd }}$ ed. Singapore: John Wiley \& Sons, 2010.

[7] C. J. Wardenand H. Chang, "Is English a brand: The impact of English language learning on product evaluation?" The Journal of Language for International Business, vol. 17, no. 1, pp. 29-41, 2006.
[8] F. Liu, J. M. Li, and J. X. Liu, "English and Chinese? The role of consumer ethnocentrism and country of origin in Chinese attitudes towards Store Signs," Australasian Marketing Journal, vol. 14, no. 2, pp. 5-17, 2006.

[9] A. P. C. Hsu and S. Kundu, "Country of origin image: measurement and cross national testing," Journal of Business Research, vol. 58, pp. 103-106, 2005.

[10] R. A. Haefner and J. J. Lee, "Global brands in the context of china: insights into Chinese consumer decision making," International Journal of China Marketing, vol. 3, no. 1, pp. 20-43, 2012.

[11] S. D. Grey, J. Haefner, and A. Rosenbloom, "The role of global brand familiarity, trust and liking in predicting global brand purchase intent: a Hungarian-American comparison," International Journal of Business and Emerging Markets, vol. 4, no. 1, pp. 4-27, 2012.

[12] A. Rosenbloom, A. Marcheva, and J. Haefner, "Global brand perceptions of Bulgarian consumers: Some contemporary insights," Mechanisms for Managing the Development of Socio-Economic Systems, pp. 269-276, 2011.

[13] T. Shimp and S. Sharma, "Consumer ethnocentrism: Construction and validation of CETSCALE," Journal of Marketing Research, vol. 24, no. 3, pp. 280-289, 1987.

[14] G. Balabanis and A. Diamantopoulos, "Domestic country bias, country-of-origin effects, and consumer ethnocentrism: A multidimensional approach," Journal of the Academy of Marketing Science, vol. 32, no. 1, pp. 80-95, 2004.

[15] E. Kaynak and A. Kara, "Consumer perceptions of foreign products," European Journal of Marketing, vol. 36, pp. 928-950, 2002.

[16] S. N. Furrer and O. M. Ostinell, "To localize or to standardize on the web," Multinational Business Review, vol. 12, no. 1, pp. 69-88, 2004.

[17] B. J. Calder, L. W. Phillips, and A. M. Tybout, "Designing research for application," Journal of Consumer Research, vol. 8, pp. 197-207, 1981.

[18] R. W. Brislin, "Back-translation for cross-cultural research," Journal of Cross-Cultural Psychology, vol. 1, no. 3, pp. 185-216, 1970.

[19] G. T. M. Hult, D. J. Ketchen, D. A. Griffith, C. A. Finnegan, T. G Padron, N. Harmancioglu, Y. Huang, M. B. Talay, and S. T. Cavusgil, "Data equivalence in cross-cultural international business research: Assessment and guidelines," Journal of International Business Studies, vol. 39, pp. 1027-1044, 2008.

[20] S. Burton, D. R. Lichteenstein, R. Netemeyer, and J. A. Garretson, "A scale for measuring attitude towards private label product and an examination of its psychological and behavioral correlates," Academy of Marketing Science, vol. 26, no. 4, pp. 293-306, 1998.

[21] E. Kaynakand S. T. Cavusgil, "Consumer attitudes towards products of foreign origin: Do they vary across product classes," International Journal of Advertising, vol. 2, no. 2, pp. 147-157, 1983.

[22] R. P. Bagozzi and Y. Yi, "On the evaluation of structural equation models," Journal of the Academy of Marketing Science, vol. 16, pp. 74-94, 1998.

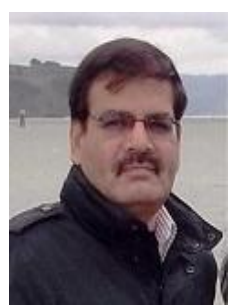

Mahmood A. Awan is an associate professor at SolBridge International School of Business, Daejeon, South Korea. He got his $\mathrm{PhD}$ degree in business administration with specialization in internet marketing from Northcentral University in Arizona, USA. He got the MBA degree from Alabama A \& M University. He is a chartered marketed (CM) and has over 15 years of industry experience as well as over 12 years of Academic experience.

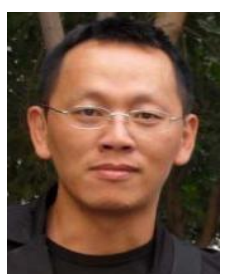

Han-Chiang $\mathrm{Ho}$ is an assistant professor at SolBridge International School of Business, Daejeon, South Korea. He got his $\mathrm{PhD}$ degree in quantitative method and business administration with specialization in marketing from Carlos III University of Madrid in Madrid, Spain. His main field of research is specifically into gender and cross-cultural difference, and co-branding strategy. 